\title{
Job insecurity, subjective well-being and job performance: the moderating role of growth mindset
}

\author{
Epic Anung Anindita Setjo ${ }^{1}$ and Rosaly Fransiska ${ }^{1}$ \\ ${ }^{1}$ Department of Management, Faculty of Economics and Business, Universitas Kristen Satya Wacana, Indonesia
}

This study aims to analyze the impact of job insecurity on subjective well-being and the
impact on job performance, with a growth mindset as the moderating variable. The COVID-
19 pandemic has been running for more than 1 year and this research was conducted during
the pandemic period. Due to the COVID-19 pandemic, many companies and other units
were adversely affected so that the companies' performance declined, PT Armada Finance
is one of those. Therefore, this study expected that job insecurity influences subjective well-
being, and subjective well-being influences job performance. Furthermore, a growth
mindset is also expected to have a moderating influence on the subjective well-being of the
employees to increase job performance. The results of regression and moderated
regression analysis (MRA) on 75 samples collected from employees of PT Armada Finance
company in Magelang, Central Java, Indonesia, show that job insecurity does not influence
subjective well-being. The result also shows that subjective well-being has a positive
influence on job performance. In addition, this study also suggests that having a growth
mindset could be moderating subjective well-being to increase job performance.

Keywords

job insecurity; subjective well-being; job performance; growth mindset

\section{INTRODUCTION}

On $2^{\text {nd }}$ March 2020, the government of Indonesia confirmed the first Covid-19 case (Putri, 2020). On $15^{\text {th }}$ March 2020, Joko Widodo, the President of Indonesia, said that Indonesians had to study and work from home (Ratriani, 2020). Many companies and industries had reduced and even stopped their operation to obey the government's regulations. The economic activities were obstructed and, in the long-term, the outbreak of Covid-19 will cause business bankruptcy, employees' layoffs, unemployment, and rising crime rates (Zhang et al., 2020). According to Liputan 6 news, Suhariyanto, the Head of BPS (Badan Pusat Statistik), Indonesian economy was contracted by $5.32 \%$ (Fanani, 2020). The economy of Indonesia became disrupted (Nasution et al., 2020). Many companies have made gradual adjustments to the development of Covid-19 by cutting working hours with the consequence of cutting wages. The companies can cut employee salaries by almost $50 \%$ and even lay off employees who protested and were less productive (Novika, 2020). The COVID-19 pandemic is still a scourge for all parties, even a new type of COVID has been confirmed (Bestari, 2021). Therefore, in this pandemic, job insecurity may have a greater impact on subjective well-being than usual. However, if viewed from another perspective, this high job insecurity might make employees more careful, passionate, and try to give the best performance in the hope that they can continue to work.

Lin et al., (2021) stated that Covid-19 has an implication on the job insecurity of the employees and it will impact the outcome of the employees. According to Darvishmotevali and Ali (2020); (Jung et al., 2021); Lin et al., (2021), these phenomena can increase job insecurity because job insecurity defines as everyone's matter regarding their work and the future sustainability and job insecurity can act as a significant stressor for employees. Sinaga (2018) stated that job insecurity can reduce the subjective well-being felt by employees because they feel tension, anxiety, worry, and stress. Diener, Oishi, and Lucas (2015); Jach et al. (2018) stated that subjective wellbeing is a broad picture that refers to all forms of evaluating a person's life or emotional experiences, which include satisfaction, high positive affect, and low negative affect as the components. Moreover, subjective well-being has a 
positive impact on job performance (Bryson et al., 2017) because, by having a good positive emotion, the employee will have good creativity, understanding, and mental health so that those will result in a good performance (Ariati, 2010); (Hazelton, 2014). As it is explained on the literatures above, that subjective well-being will positively impact job performance. However, if we spot at the current conditions, it is possible that subjective well-being does not always have an impact on job performance because this condition creates a very large workload, strict health protocols, and strict requirements when on duty out so that it might make their performance low. According to the literatures above, it is predicted that job insecurity can reduce the subjective well-being of the employees and affect the job performance of the employees.

According to Mas'udah (2019); Anggayani and Hartawan (2019); Kouzes and Posner (2019); Jach et al. (2018); Zhao et al. (2021), a growth mindset is a mindset that believes that a person's abilities and psychology will develop when they face a problem and try to solve it because they see a challenge as an opportunity to learn so that they are always optimistic about the future and always confident in solving problems. Anggayani and Hartawan (2019) stated that optimism enables a person to assess stressful events more positively and helps mobilize resources to take steps to deal with stressors. In addition, people with a growth mindset tend to love learning and seek feedback which improves their performance (Cutumisu \& Lou, 2020) and it suggests that having a growth mindset may increase the job performance of a person (Cutumisu \& Lou, 2020). It is expected that having a growth mindset can moderate the subjective well-being of the employees to increase job performance.

Although many Indonesians know about the growth mindset, many people still have not implemented it yet. According to the Program for International Student Assessment (PISA) Results, the majority of students in The Organization for Economic Co-operation and Development (OECD) member countries have a growth mindset, but many Indonesians have not implemented a growth mindset. This data is used by this study because it is expected that students will become employees in the future. Based on the data in Figure 1, Indonesia is in the third lowest rank from 78 OECD member countries, with only $28.5 \%$ students population have a growth mindset (OECD 2019). This data shows that a lot of Indonesian people still have a fixed mindset rather than a growth mindset and are still left behind from other countries. Hence, it is

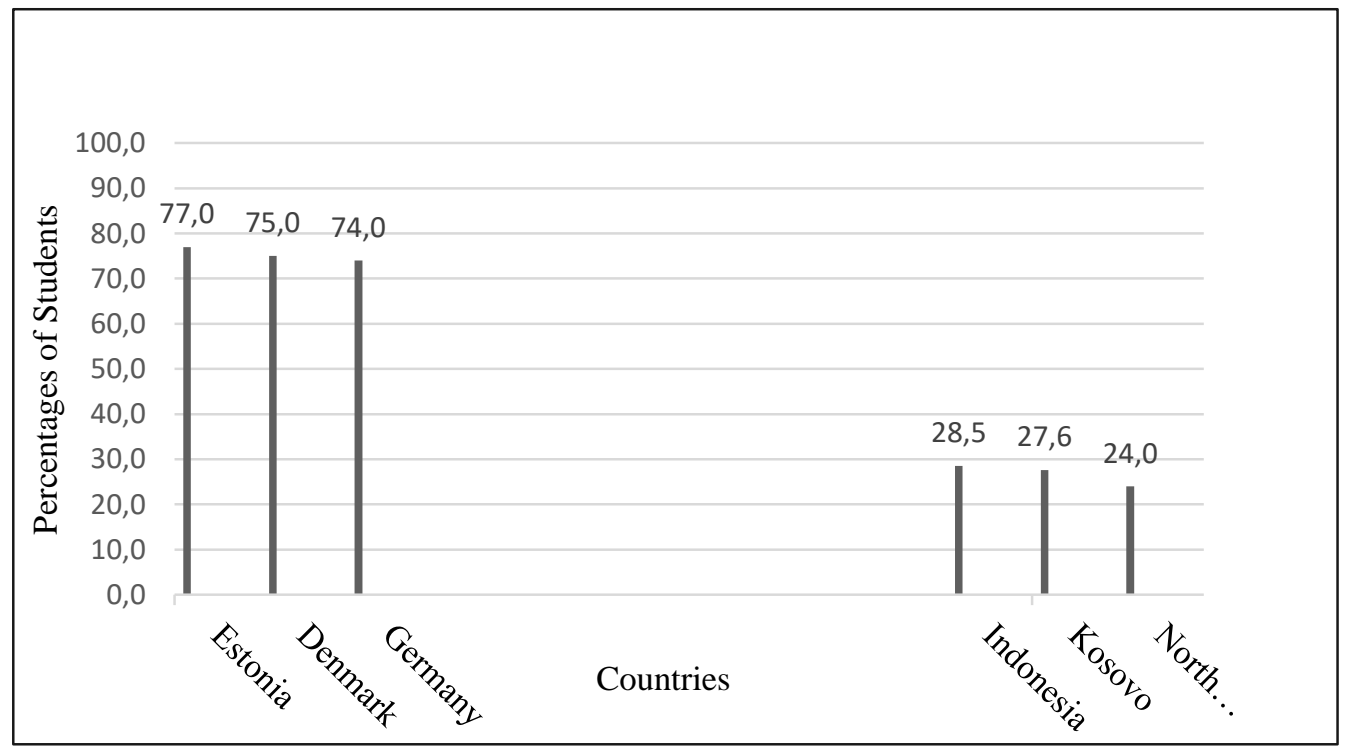

Note. Adapted from Growth Mindset | PISA 2018 Results (Volume III) - (The Organisation for Economic Co-operation and Development (OECD), 2019a)

Figure 1.

Growth mindset percentages of students in difference countries 
expected that having a growth mindset is important nowadays. In addition, the growth mindset is chosen as the moderating variable for subjective well-being and job performance because the growth mindset has the power to predict positive psychological results relates to the selfregulatory process. There are 3 approaches to gain self-regulation, which are learningoriented goal setting, working towards a goal, and optimism during goal monitoring, and those approaches help to booster the subjective well-being of the people because build positive emotion up (Zhao et al., 2021) and also growth mindset brings a positive effect on job performance as people will motivate themselves for coping problems (Wiguna \& Netra, 2020) so that it will help to deal with this situation.

Bryson et al., (2014); Sinaga (2018); Darvishmotevali and Ali (2020) stated that job insecurity has a significant negative relationship with subjective well-being, while Purba and Suyasa (2019) stated that job insecurity does not have a significant relationship with subjective well-being. Ulfa (2017) stated that job insecurity is not affecting the whole components of subjective well-being but only has a little negative influence on affection component. Wening (2005) stated that job insecurity does not influence job satisfaction, while job satisfaction is considered as the cognitive component of subjective well-being. Besides that, Bakker and Oerlemans (2014); Bryson et al., (2014); and Darvishmotevali and Ali (2020) said that subjective well-being has a high positive influence on job performance. Magnier-Watanabe et al. (2020) stated that subjective well-being does not have any impact on job performance. Daniels and Harris (2000); Nabawi (2019) stated that job satisfaction, as the cognitive component of subjective well-being, does not have a significant impact on job performance. Based on the inconsistency of results from previous studies, and the missing element of growth mindset, this research will combine, and analyze the influence of job insecurity on subjective well-being and the influence of subjective well-being on job performance, with an additional growth mindset as moderating variable.

After the preliminary study was conducted, it was found that PT. Armada Finance (AF) Magelang is one of the companies affected by the Covid-19 outbreak. PT. AF was founded as a financial obligation company, and the head office of PT. AF is in Magelang, Central Java (PT. Armada Finance, 2019). Based on the preliminary interview with the Finance and Accounting Manager of PT. AF, it is known that there was a declining profit from the target by $26.25 \%$ in 2020 . Other than that, based on the preliminary interviews with the Head of Human Resource Department (HRD), PT AF has made several policies to sustain the company, which are compressing the work hours, making the work schedules for working from home (WFH), cutting the employees' salaries by $20 \%$, and firing 32 field workers who were not productive. Besides, PT AF has 31 subbranch offices but because of this condition, 9 sub-branch offices (i. e. sub-branch offices in Bumiayu, Wonosari, Bengkalis, Tanjung, Palangkaraya, Boyolali, Kuansing, Blitar, and Banjarnegara) were closed by PT AF because of unproductiveness. Because of the decisions above, employees are being affected by the policies set by PT. AF. The Head of HRD stated that almost all the employees, from 75 employees, are feeling less motivated because of the wages and conditions, insecure of the uncertainty, worried about their work, and less effective in terms of work.

Building on the phenomenon and literature above, the research questions of this study are: 1) does job insecurity influence subjective well-being?; 2) does subjective well-being influence job performance?; 3) does growth mindset moderate the influence of subjective wellbeing on job performance? The purposes of this study are: 1) to examine the influence of job insecurity on subjective well-being; 2) to examine subjective well-being influences job performance; and 3) to examine whether growth mindset moderates the influence of subjective well-being on job performance at PT. Armada Finance Employees. The contribution of this study is to provide information to readers that have a growth mindset and focus on developing positive subjective well-being can be essential. This study is also expected to help PT Armada Finance to know and understand the psychological condition of the employees. It is also expected by this study, that employees can also understand the importance of having a growth mindset to deal with this challenging situation. 


\section{LITERATURE REVIEW AND HYPOTHESES DEVELOPMENT}

Mangkunegara (2009) stated that job performance is defined as the quality and quantity of work achieved by an employee in carrying out his duties under the responsibilities assigned to him/her. Having high job performance is important, and it will help to achieve organizational goals. The employee will have a more competitive capacity and it will increase their selfconfidence and job satisfaction (Akgunduz, 2015). Having high job performance will also increase their professional skills opportunity for career development and goals (Sungu et al., 2019).

According to Mangkunegara (2009), the indicators of job performance are 1) quality: how well an employee does what should be done, 2) quantity: how long an employee works in one day, and this can be seen from the speed of each employee, 3) implementation of tasks: how far the employee can do his job accurately or without mistakes, and 4) responsibility: awareness of the employee's obligation to carry out the work given by the company.

Adkins et al., (2001) stated that job insecurity is a feeling of powerlessness to maintain the desired job security under threatened working conditions. According to Adkins et al., (2001), indicators for job insecurity are: 1) the possibility of negative changes that occur in the company that threatens aspects of work, 2) the possibility of losing their jobs, and 3 ) the helplessness of employees in dealing with threats in aspects of work.

Diener, Oishi, and Lucas (2015) stated that subjective well-being is a broad picture that refers to all forms of evaluating a person's life or emotional experiences, which include satisfaction, high positive affect, and low negative affect. Diener, Oishi, and Lucas (2015); Jach et al. (2018); stated that subjective well-being can be assessed from two components, which are: 1) cognitive component: the cognitive component of subjective well-being describes the self-evaluation felt by individuals about their perceived life satisfaction in general (i.e. job, relationships, etc.), 2) An affective component: The affective aspect of subjective well-being describes the affective evaluation that individuals perceive about positive affect, when they feel pleasant feelings (i.e. pleasure, love, happiness, etc.) and negative affect, when they feel unpleasant feelings (i.e. guilt, anger, sadness, etc.).

In recent years, many studies have discussed the growth mindset. According to Mas'udah (2019), a growth mindset is a mindset that believes a person's potential and psychological attributes can develop through deeper training and efforts to face increasing difficulties. According to Mas'udah (2019), a growth mindset can be measured from four aspects, which are: 1) belief in intelligence: the belief that talents, is the basic ability of a person to learn in a shorter time than other people but have more optimal results. Meanwhile, the character is the value that a person has, and it can influence all thoughts, behavior, trait, and manner of the individual, and can be developed, 2) belief that effort and hard work contribute to success: the belief that effort and hard work can go well to achieve a goal and will be successful, and avoid negative thoughts about failure, 3) belief in challenges, difficulties, obstacles, important for self-development: the belief that the difficulties and challenges which will occur in life are a process of self-development, 4) belief in criticism and suggestions from others is feedback on the success: the belief that getting criticism from others is a means to learn and do self-improvement to achieve success.

\section{The influence of job insecurity on subjective well-being}

Job insecurity can spread among employees for two specific reasons. The first reason is because of changes in the organization. The second reason is because of certain threats that occur at work. But the most important is that job insecurity can act as a significant stressor for employees (Jung et al., 2021). Sinaga (2018); Rizky and Sadida (2019) stated that employees can feel positive subjective well-being when their job is no longer a burden. They can enjoy work and feel satisfied with the life they live. Sinaga (2018) stated that job insecurity can reduce the subjective well-being felt by employees because they feel tension, anxiety, worry, and stress. Therefore, the hypothesis is formulated as below:

H1: Job insecurity negatively influences the subjective well-being of the employee 


\section{The influence of subjective well-being on job performance}

Jach et al. (2018) stated that subjective wellbeing has cognitive and affective components. The affective component deals with a person's affective reactions when evaluating conditions and events in his or her life and is divided into two, which are positive affect and negative affect. The cognitive component refers to the person's overall evaluation of their life and satisfaction globally, including physical and mental health, and also work (Situmorang and Tentama, 2018). Hence, subjective wellbeing has a positive impact on work performance (Bryson et al., 2017). By having a good positive emotion, the employee will have good creativity, understanding, and mental health so that those will result in a good performance (Hazelton, 2014). Peterson et al. (2011) stated that an individual who has higher subjective wellbeing will show a better job performance. Therefore, the hypothesis is formulated as below:

H2: Subjective well-being positively influences the job performance of the employee

\section{The moderating role of growth mindset on the effect of subjective well-being on job performance}

According to Mas'udah (2019); Zhao et al. (2021); Kouzes and Posner (2019); Jach et al. (2018) people with a growth mindset believe that failure and challenge are a lesson for the future. They can build positive psychological outcomes and are always optimistic about the future. Anggayani and Hartawan (2019) stated that, the higher individual's confidence in facing situations that threaten that individual, the more the individual will avoid stress. Moreover, optimism enables a person to assess stressful events more positively and helps mobilize resources to take steps to deal with stressors (Anggayani and Hartawan, 2019). People that assess the work environment positively as attractive, fun, and full of challenges are considered to have good subjective well-being. It can be said that they feel happy and will show optimal performance (Ariati, 2010). Therefore, the hypothesis is formulated as below:
H3: Growth mindset moderates the positively influence of subjective wellbeing on job performance

\section{METHODS}

The type of research used is causality quantitative research. Causality quantitative research is a purposeful research design that determines the relationship and influence of a variable on other variables (Sugiyono, 2010). The COVID-19 pandemic has been going on for about 20 months. Many companies have made efficiencies, cut employee salaries, and other decisions to survive in this condition. Therefore, in May 2021 this research was conducted offline. The type of data used is primary data through an offline survey in PT. Armada Finance as the population, using saturated sample with all employees, 75 employees, were used as the samples. The questionnaires were tested by validity test and reliability test. The respondents were characterized by gender, age, position, length of work, status, and the number of dependents. Based on the resulted data on the table 1, the majority of respondents were female employees, the most dominating age is the age range of 36th - 50th years old, the majority of respondents positions were staff, the most numbers of lengths of work were 120 , the majority of respondents status were married, and the majority of number of dependents were 0 and 2 .

\section{Measurements}

\section{Job performance}

Job performance is defined as the quality and quantity of work achieved by an employee in carrying out his duties under the responsibilities assigned to him/her (Mangkunegara, 2009). This variable was measured using with 13 question items developed by Mangkunegara (2009). It was measured using Likert scale with 6 points measurement scales. Those 6 points are 6 for very strongly agree, 5 for strongly agree, 4 for agree, 3 for disagree, 2 for strongly disagree, and 1 for very strongly disagree. One example statement item is "I always do my assignments correctly without any errors". The reliability result for job performance is reliable with Cronbach Alpha $0.910>0.70$ and 13 total items. 


\section{Job insecurity}

Job insecurity is a feeling of powerlessness to maintain the desired job security under threatened working conditions (Adkins et al., 2001). This variable was measured using 4 question items developed by Adkins et al. (2001). It was measured using Likert scale with 6 points measurement scales. Those 6 points are 6 for very strongly agree, 5 for strongly agree, 4 for agree, 3 for disagree, 2 for strongly disagree, and 1 for very strongly disagree. One example statement item is "I do not have the strength to face the threats that occur in my work". The reliability result for job insecurity is reliable with Cronbach Alpha $0.726>0.70$ and 4 total items.

\section{Subjective well-being}

Subjective well-being is a broad picture that refers to all forms of evaluating a person's life or emotional experiences, which include satisfaction, high positive affect, and low negative affect (Diener et al., 2015). This variable was measured using 5 question items developed by (Diener et al., 2015). It was measured using Likert scale with 6 points measurement scales. Those 6 points are 6 for very strongly agree, 5 for strongly agree, 4 for agree, 3 for disagree, 2 for strongly disagree, and 1 for very strongly disagree. One example statement item is "I am very satisfied with my current job". The reliability result for subjective well-being is reliable with Cronbach Alpha $0.728>0.70$ and 6 total items.

\section{Growth mindset}

A growth mindset is a mindset that believes a person's potential and psychological attributes can develop through deeper training and efforts to face increasingly difficulties (Mas'udah, 2019). This variable was measured using 12 question items developed by Mas'udah (2019). It was measured using Likert scale with 6 points measurement scales. Those 6 points are 6 for very strongly agree, 5 for strongly agree, 4 for agree, 3 for disagree, 2 for strongly disagree, and 1 for very strongly disagree. One example statement item is "I have a high willingness to accept criticism and input from others". The reliability result for growth mindset is reliable with Cronbach Alpha $0.920>0.70$ and 12 total items.

\section{RESULTS AND DISCUSSION}

\section{Validity}

This study tested the data using SPSS V.21 software. The first step in processing data was by conducting a validity. The items consisted of 34 item statements including 13 items representing job performance, 4 items representing job insecurity, 5 items representing subjective well-being, and 12 items representing growth mindset. The number of questionnaires shared is 75 and there were 2 unfit questionnaires, so that the questionnaires could be used is 73 . When $N$ $=73$, the value of rtable is 0.227 . It is known that each statement item used in the questionnaire has rcount that is greater than rtable with a significance level of 0.05 . This shows that the instrument used in this study is valid and can be used.

\section{Descriptive results}

The descriptive results show that the Job Performance variable is 5.13 which is included in the very high category. Job Insecurity variable is 3.69 which is included in the medium category. Subjective WellBeing variable is 4.74 which is included in the high category. In addition, Growth Mindset variable is 5.31 which is included in the very high category.

\section{Hypothesis testing results}

Based on Table 1, the results of hypothesis testing show a simple linear regression model from a linear equation for the first hypothesis $\left(\mathrm{H}_{1}\right)$, which is $\mathrm{Y}=4.718+$ $0.016 \mathrm{X} 1+$ e. In Table 1, it was mentioned that Job Insecurity $\left(X_{1}\right)$ as the independent variable has no influence to Subjective WellBeing $(Y)$ as the dependent variable. It is indicated by the significance value is 0.804 $>0.05$ so it can be concluded that the first hypothesis $\left(\mathrm{H}_{1}\right)$ which states that Job Insecurity influences Subjective Well-Being is rejected and Ho accepted.

Based on Table 1 the results of hypothesis testing also show a simple linear regression model from a linear equation for the second hypothesis $\left(\mathrm{H}_{2}\right)$, which is $\mathrm{Y}=$ $3.644+0.311 \mathrm{X} 2+$ e. In Table 1 , it is mentioned that Subjective Well-Being $\left(X_{2}\right)$ as an independent variable influences the Job Performance $(Y)$ as the dependent variable. It is indicated by the value of the 
Table 1.

Hypotheses testing results

\begin{tabular}{|c|c|c|c|c|c|c|}
\hline Independent Variable & $\begin{array}{l}\text { Dependent } \\
\text { Variable }\end{array}$ & Constant. & Sig. & $\begin{array}{l}\text { Unstd. } \\
\text { Coeff. } \\
\text { Beta }\end{array}$ & $\mathbf{R}^{2^{*}}$ & Conclusion \\
\hline Job Insecurity & $\begin{array}{l}\text { Subjective Well- } \\
\text { Being }\end{array}$ & 4.718 & 0.804 & 0.016 & 0.001 & H1: Rejected \\
\hline Subjective Well-Being & Job Performance & 3.644 & 0.002 & 0.311 & 0.130 & H2: Accepted \\
\hline Subjective Well-Being & & & 0.193 & -0.218 & & \\
\hline $\begin{array}{ll}\text { Subjective } & \text { Growth } \\
\text { Well-Being } & \text { Mindset }\end{array}$ & Job Performance & 3.987 & 0.000 & 0.086 & $0.255^{*}$ & H3: Accepted \\
\hline
\end{tabular}

${ }^{*}$ Adj. $\mathbf{R}^{2}$

Subjective Well-Being $\left(\mathrm{X}_{2}\right)$ regression coefficient of 0.311 in the simple linear regression equation model, which is $\mathrm{Y}=$ $3.644+0.311 \times 2+e$. It is also known that the significance value for the influence of Subjective Well-Being on Job Performance is $0.002<0.05$ so it can be concluded that the second hypothesis $\left(\mathrm{H}_{2}\right)$ that states Subjective Well-Being influences to Job Performance is accepted and $\mathrm{Ho}$ is rejected. It means there is partial influence to Job Performance with positive direction so that the higher the Subjective Well-Being, the higher the Job Performance of the employees.

Based on Table 1 the results of hypothesis testing also show a moderating regression model from the regression equation for the third hypothesis $\left(\mathrm{H}_{3}\right)$, which is $Y=3.987-0.218 X 1+0.086 \mathrm{X} 1 \mathrm{X} 2+\mathrm{e} . \mathrm{In}$ Table 1 , it is mentioned that the multiplication of Subjective Well-Being and Growth Mindset $\left(X_{2}\right)$ as the independent variable increase the influence of the Subjective Well-Being on the Job Performance $(Y)$ as the dependent variable. It is indicated by the significance value of the moderating results which is $0.000<0.05$. Therefore, it can be concluded that the third hypothesis $\left(\mathrm{H}_{3}\right)$ which states that Growth Mindset moderates the influence of Subjective Well-being on Job Performance is accepted and Ho is rejected. Moreover, Growth Mindset moderates by strengthening the influence of Subjective Well-Being on Job Performance by showing the increasing adjusted $R_{2}$ from $13 \%$ to $25.5 \%$.

\section{CONCLUSION}

Based on the data analysis and discussion in the previous sections, it can be concluded that: 1) Job insecurity does not influence the subjective well-being of PT Armada Finance employees. 2) Subjective well-being has an influence to the job performance of PT Armada Finance employees and it is known that subjective well-being has a positive effect. 3) The growth mindset moderates by strengthening the influence of subjective well-being on job performance. In addition, the change in adjusted $R_{2}$ from $13 \%$ to $25.5 \%$ indicates that there is a moderation in the growth mindset.

This research supports researches from Purba and Suyasa (2019); Ulfa (2017); Bryson et al., (2017); Bakker and Oerlemans (2014); Bryson et al., (2014); Mas'udah (2019); Zhao et al. (2021); Kouzes and Posner (2019) and does not support research from Bryson et al., (2014); Sinaga (2018); Darvishmotevali and Ali (2020); Magnier-Watanabe et al. (2020); Daniels and Harris (2000); Nabawi (2019).

This research is also used for related parties, including 1) as a suggestion for employees, it is hoped that the employees will continue to learn new things, that may be difficult to learn but important, so that later it can support work performance. After that, employees are expected to do a selfevaluation and take note the important things so that these notes can be used to see changes both from within and the work process. In addition, these notes and evaluations can be used to learn to make future work plans to be more effective and productive. This is used to hone the growth mindset of each employee. 2) PT Armada Finance can increase the motivation of the employees through the company's internal survey to find out what the employees want and need so that the company can adjust the way to motivate the most according to the wishes of employees. 3) This research is also used to help PT Armada Finance know and understand employees' psychological conditions. This research is also used to 
provide information and descriptions to employees and readers to understand the importance of having a growth mindset to face this challenging situation. Due to this situation, PT Armada Finance is suggested to conduct or join an internal seminar regularly with the related topic about growth mindset to increase the awareness and selfdevelopment of the employees about it. Another suggestion, PT Armada Finance can conduct an evaluation regularly to give feedback about employees' performance. As long as the employees implement the growth mindset, they will always accept feedback and criticism as their tools to make self-development, end up with better performance.

All in all, this research has made every effort to reach the best results, but in reality, there is still shortcoming caused by limitations, including: 1) all variables are measured through the self-perception of each respondent so that it does not rule out the possibility of bias due to overestimating on self-assessment.

Based on the results of this study, here are things that the author recommends, which are: 1) this research was only conducted on a company in the financing sector, namely PT Armada Finance in Magelang. In order to be generalized, a restudy can be carried out in different company sectors, for instance automotive, banking, manufacture, and others in the hope of knowing the psychological conditions of employees in related companies and compare them. 2) The next researcher should conduct research that focuses more on determining more appropriate and accurate indicators so that each dimension can be measured with a minimum of three indicators to be more accurate.

\section{REFERENCES}

Adkins, C. L., Werbel, J. D., \& Farh, J. L. (2001). A field study of job insecurity during a financial crisis. Group and Organization Management, 26(4), 463-483. https://doi.org/10.1177/1059601101264 004

Akgunduz, Y. (2015). The influence of selfesteem and role stress on job performance in hotel businesses. International Journal of Contemporary Hospitality Management, 27(6), 10821099. https://doi.org/10.1108/lJCHM09-2013-0421
Anggayani, L., \& Hartawan, I. G. M. . (2019). The relationship between self reliance, proactive attitude, and optimism with coping stress. Bisma The Journal of Counseling, 3(2), 74-81. https://doi.org/http://dx.doi.org/10.23887 /bisma.v3i2

Ariati, J. (2010). Subjective well-being (kesejahteraan subjektif) dan kepuasan kerja pada staf pengajar (dosen) di lingkungan fakultas psikologi Universitas Diponegoro. Jurnal Psikologi Undip, 8(2), 2-5. https://doi.org/10.14710/jpu.8.2.117123

Bakker, A. B., \& Oerlemans, W. G. M. (2014). Subjective well-being in organizations. In K. S. Cameron \& G. M. Spreitzer (Eds.), The Oxford Handbook of Positive Organizational Scholarship (Issue January 2011, pp. 178-189). Oxford University Press. https://doi.org/10.13140/2.1.1145.4723

Bestari, N. P. (2021, December 1). Covid Varian Omicron Vs Delta, Mana yang Lebih Menakutkan? CNBC Indonesia, 1. https://www.cnbcindonesia.com/tech/20 211201183032-37-295920/covidvarian-omicron-vs-delta-mana-yanglebih-menakutkan

Bryson, A., Forth, J., \& Stokes, L. (2014). Does worker wellbeing affect workplace performance? Affinity Work Health \& Wellbeing Hub, 33-50. http://affinityhealthhub.co.uk/d/attachme nts/does-worker-wellbeing-affectworkplace-performance1597230050.pdf

Bryson, A., Forth, J., \& Stokes, L. (2017). Does employees' subjective well-being affect workplace performance? Human Relations Journals, 70(8), 7-16. https://doi.org/10.1177/0018726717693 073

Cutumisu, M., \& Lou, N. M. (2020). The moderating effect of mindset on the relationship between university students' critical feedback-seeking and learning. Computers in Human Behavior, 112(106445). https://doi.org/10.1016/j.chb.2020.1064 45

Daniels, K., \& Harris, C. (2000). Work , psychological well-being and performance. Occupational Medicine, 50(5), 304-309. https://doi.org/https://doi.org/10.1093/oc cmed/50.5.304

Darvishmotevali, M., \& Ali, F. (2020). Job insecurity, subjective well-being and job 
performance: the moderating role of psychological capital. International Journal of Hospitality Management, 87(February 2019), 3. https://doi.org/10.1016/j.ijhm.2020.1024 62

Diener, E., \& Chan, M. Y. (2011). Happy people live longer: subjective well-being contributes to health and longevity. Applied Psychology: Health and WellBeing, 3(1), 1-43. https://doi.org/10.1111/j.17580854.2010.01045.x

Diener, E., Oishi, S., \& Lucas, R. E. (2015). National accounts of subjective wellbeing. American Psychologist, 70(3), 234-242.

https://doi.org/10.1037/a0038899

Fanani, F. (2020, August 5). Ekonomi Indonesia Minus 5,32 Persen, BPS Sebut Dampak Corona Luar Biasa Buruk. Liputan6.Com, 4. https://www.liputan6.com/bisnis/read/43 22960/ekonomi-indonesia-minus-532persen-bps-sebut-dampak-corona-luarbiasa-buruk

Hazelton, S. (2014). Positive emotions boost employee engagement: making work fun brings individual and organizational success. Human Resource Management International Digest, 22(1), 34-37. https://doi.org/10.1108/HRMID01-2014-0012

Jach, H. K., Sun, J., Loton, D., Chin, T. C., \& Waters, L. E. (2018). Strengths and subjective wellbeing in adolescence: strength-based parenting and the moderating effect of mindset. Journal of Happiness Studies, 19(2), 3-20. https://doi.org/10.1007/s10902-0169841-y

Jung, H. S., Jung, Y. S., \& Yoon, H. H. (2021). Covid-19: the effects of job insecurity on the job engagement and turnover intent of deluxe hotel employees and the moderating role of generational characteristics. International Journal of Hospitality Management, 92(September 2020), 2-9. https://doi.org/10.1016/j.ijhm.2020.1027 03

Kouzes, T. K., \& Posner, B. Z. (2019). Influence of managers' mindset on leadership behavior. Leadership and Organization Development Journal, 40(8), 829-833. https://doi.org/10.1108/LODJ-03-20190142

Limeri, L. B., Carter, N. T., Choe, J., Harper, H. G., Martin, H. R., Benton, A., \& Dolan, E. L. (2020). Growing a growth mindset: characterizing how and why undergraduate students' mindsets change. International Journal of STEM Education, $7(1)$ https://doi.org/10.1186/s40594-02000227-2

Lin, W., Shao, Y., Li, G., Guo, Y., \& Zhan, X. (2021). The psychological implications of COVID-19 on employee job insecurity and its consequences: The mitigating role of organization adaptive practices. Journal of Applied Psychology, 106(3), 317-329. https://doi.org/10.1037/apl0000896

Magnier-Watanabe, R., Uchida, T., Orsini, P., \& Benton, C. F. (2020). Organizational virtuousness, subjective well-being, and job performance: comparing employees in France and Japan. Asia-Pacific Journal of Business Administration, 12(2), 115-138. https://doi.org/10.1108/APJBA-102019-0210

Mangkunegara, A. A. . (2009). Manajemen Sumber Daya Manusia Perusahaan. Bandung: PT. Remaja Rosdakarya.

Mas'udah, I. (2019). Pengaruh growth mindset terhadap grit akademik pada mahasiswa yang mengikuti organisasi [Universitas Negeri http://lib.unnes.ac.id/id/eprint/33657 Semarang].

Nabawi, R. (2019). Pengaruh lingkungan kerja, kepuasan kerja dan beban kerja terhadap kinerja pegawai. Maneggio: Jurnal IImiah Magister Manajemen, 2(2), 170-183. https://doi.org/10.30596/maneggio.v2i2. 3667

Nasution, D. A. D., Erlina, E., \& Muda, I. (2020). Dampak pandemi covid-19 terhadap perekonomian Indonesia. Jurnal Benefita, 5(2), 213-214. https://doi.org/10.22216/jbe.v5i2.5313

Novika, S. (2020). Kisah pilu karyawan swasta, gaji melayang $50 \%$ diterjang corona. DetikFinance. https://finance.detik.com/beritaekonomi-bisnis/d-4981121/kisah-pilukaryawan-swasta-gaji-melayang-50diterjang-corona/2

Peterson, S. J., Luthans, F., Avolio, B. J., Walumbwa, F. O., \& Zhang, Z. (2011). Psychological capital and employee performance: a latent growth modeling approach. Personnel, 64(2), 427-450. https://doi.org/doi:10.1111/j.17446570.2011.01215.x 
PT. Armada Finance. (2019). Company Profile of Armada Finance. Armada Finance. https://af.co.id/en/?p=34

Purba, T. M., \& Suyasa, P. T. Y. S. (2019). Pengaruh rasa tidak aman bekerja terhadap subjective well-being dan kualitas tidur dengan job embeddedness sebagai moderator. Jurnal Muara IImu Sosial, Humaniora, Dan Seni, 3(1), 7-9. https://doi.org/10.24912/jmishumsen.v3i 1.3556

Putri, G. S. (2020, October 23). Menelusuri klaster pertama penularan covid-19 di Indonesia halaman all - Kompas. Www.Kompas.Comompas.Com. https://www.kompas.com/sains/read/20 20/10/23/090200623/menelusuriklaster-pertama-penularan-covid-19-diindonesia?page $=$ all

Ratriani, V. R. (2020, March 16). Jokowi instruksikan bekerja dari rumah, ini arti work from home halaman 2 - Kompas. Www.Kompas.Com, 1. https://www.kompas.com/tren/read/202 0/03/16/195035165/jokowi-instruksikanbekerja-dari-rumah-ini-arti-work-fromhome?page $=2$

Rizky, T. R., \& Sadida, N. (2019). Hubungan antara job insecurity dan employee well being pada karyawan yang bekerja di perusahaan yang menerapkan PHK di DKI Jakarta. Empati, 8(1), 329-335. https://ejournal3.undip.ac.id/index.php/e mpati/article/view/23651

Sinaga, A. N. C. (2018). The relationship between job insecurity and subjective well-being of outsourcing. Jurnal Kognisia, 1(1), 65-66.

https://doi.org/doi.org/10.20527/jk.v1i1. 1390

Situmorang, N. Z., \& Tentama, F. (2018). Faktorfaktor yang mempengaruhi subjective well-being pada ibu jalanan [Ahmad Dahlan Yogyakarta University]. https://doi.org/10.31227/osf.io/pxg7u

Sugiyono, S. (2010). Metode penelitian kuantitatif, kualitatif dan $R \& D$ (2nd ed.). ALFABETA.

https://www.pdfdrive.com/prof-drsugiyono-metode-penelitian-kuantitatifkualitatif-dan-rd-intro-d56379944.html

Sungu, L. J., Weng, Q., \& Xu, X. (2019). Organizational commitment and job performance: examining the moderating roles of occupational commitment and transformational leadership. International Journal of Selection and Assessment, 27(3), 280-290. https://doi.org/10.1111/ijsa.12256
The Organisation for Economic Co-operation and Development (OECD). (2019a). Growth mindset | PISA 2018 results (volume III) : what school life means for students' lives / OECD iLibrary. OECD ILibrary Organization.

https://doi.org/doi.org/10.1787/bd69f80 5-en

The Organisation for Economic Co-operation and Development (OECD). (2019b). Programme for international student assessment (PISA) results from PISA $2018 . \quad$ In OECD. https://doi.org/https://doi.org/10.1787/ac d78851-en

Ulfa, T. Y. (2017). Pengaruh job insecurity terhadap subjective well-being dengan employability sebagai variabel moderator pada karyawan outsourcing di wilayah Kabupaten Sidoarjo [Universitas Airlangga, Surabaya, Jawa Timur]. http://repository.unair.ac.id/59755/

Wening, N. (2005). Pengaruh ketidakamanan kerja (job insecurity) sebagai dampak restrukturisasi terhadap kepuasan kerja, komitmen organisasi dan intensi keluar survivor. Kinerja, 9(2), 135-147. https://scholar.google.com/citations?us er=kL3KVIIAAAAJ\&hl=en\&oi=sra\#d=gs md_cita-

$\overline{\mathrm{d}} \& \mathrm{u}=\% 2 \mathrm{~F}$ citations\%3Fview op\%3Dvie w_citation\%26hl\%3Den\%26user\%3DkL 3KVIIAAAAJ\%26citation for view\%3D kL3KVIIAAAAJ\%3AzYLM77Y9'cAGgC\% 26 tzom\%3D-420

Wiguna, I. W. E., \& Netra, I. G. S. K. (2020). The influence of growth mindset, selfefficacy, and emotional intelligence on employee performance at Jimbaran Bay Beach Resort and Spa. American Journal of Humanities and Social Sciences Research (AJHSSR), 4(12), 175-179. https://www.ajhssr.com/wpcontent/uploads/2020/12/X2041217517 9.pdf

Zhang, D., Hu, M., \& Ji, Q. (2020). Financial markets under the global pandemic of COVID-19. Finance Research Letters, 36(March), 2-4. https://doi.org/10.1016/j.frl.2020.101528

Zhao, S., Du, H., Li, Q., Wu, Q., \& Chi, P. (2021). Growth mindset of socioeconomic status boosts subjective well-being: a longitudinal study. Personality and Individual Differences, 168(July 2020), 2-5. https://doi.org/10.1016/j.paid.2020.1103 01 